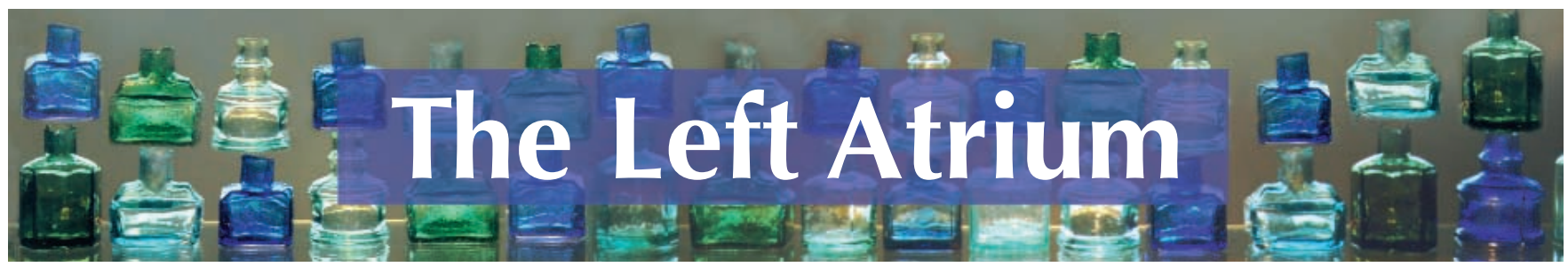

\section{Journal of the AIDS years}

AIDS activist: Michael Lynch and the politics of community Ann Silversides

Toronto: Between the Lines; 2003

pp $273 \$ 24.95$ (paper) ISBN 1-896357-73-3

$M$ ore than twenty years after the first puzzling reports of Pneumocystis carinii pneumonia among gay men in California ushered in the North American era of HIV/AIDS, comes an inspiring history of the early days of the AIDS crisis in this country. AIDS Activist: Michael Lynch and the Politics of Community is an effective combination of biography and history, a skillful personal and political narrative centred on the life of a courageous AIDS activist, Michael Lynch (1944-1991).

Ann Silversides, a Toronto-based journalist and broadcaster, has been writing on AIDS-related issues since the earlier 1980s. Silversides draws on Lynch's diaries, letters and poems, interviews with family (including his former wife, Gail, and his son, Stefan), friends, lovers and colleagues. Ultimately, the success of the book derives from Lynch's 65-volume personal diary, which now allows him to speak to us in his own words.

Lynch played a pivotal role in organizing the gay community when the AIDS crisis first hit in the early 1980s. An English Professor at the University of Toronto, he was well known and politically experienced. As a regular contributor to the Toronto gay liberation journal, The Body Politic, Lynch was one of the first to write critically about AIDS. Amid the panic of this unknown disease and the stigma associated with it, he appealed to the gay community for a calm, organized, cohesive and informed community-based response.

Lynch was a founder of the AIDS Committee of Toronto and of AIDS Action Now!, and was the driving force behind the creation of the AIDS Memorial in Toronto. Under Lynch's guidance, the gay community clearly took a leadership role in the early part of the emerging epidemic. Ultimately, it was not the health authorities but the gay community, through ACT, that undertook the first education and safer sex campaigns. Lynch was critical of government, health officials, scientific authorities and pharmaceutical companies. AIDS Action Now! worked tirelessly to make experimental medications available to people living with AIDS. Several well-organized protests highlighted the lack of government leadership in the testing and release of promising new drugs. At a Toronto protest in 1986, Lynch declared, "A government which denies Canadians drug access is a government which contributes to the deaths of Canadians." Indeed, it was only at the Fifth International Conference on AIDS, held in 1989 in Montreal, that then Prime Minister Brian Mulroney, after five years in office, made his first public remarks on AIDS.

People with AIDS were perhaps the first patient group to became as expert as their physicians in the struggle to keep up with rapidly evolving knowledge. Lynch, along with other activists, demanded patient representation within official AIDS government agencies and committees. These advocates would end up playing a central role in driving the agenda for drug research and early access to new medications. Their achievements would help pave the way for other patient groups in the future, who would go on to adopt some of the same policies and tactics as AIDS activists.

Silversides' account highlights a particularly bleak period in the AIDS epidemic. Treatment options were limited and largely ineffective, and the death toll mounted. AIDS was a polarizing issue and one that society, including governments, universities and medical faculties, was reluctant to address. Clearly, Lynch and his colleagues were frustrated by a fearful public, a conservative medical establishment, indifferent governments and the stigma of living with AIDS. Around 1987, AIDS patients in the Toronto area finally began to receive compassionate medical care from a dedicated group of primary care physicians (HIV Primary Care Physicians Group), who committed themselves to increasing their knowledge and awareness while acting as patient advocates.

Through Lynch's poetry and AIDS elegies, such as those included in These Waves of Dying Friends (1989) and inscribed on the Toronto AIDS memorial, you can't help but feel a real sense of doom, desperation and helplessness as dozens of his close friends and colleagues perished. Through all of his accomplishments, Lynch was waging his own war against the HIV virus. In 1991, at age 46, Lynch succumbed to AIDS.

With the advent of antiretroviral medications in Canada and the significant reduction in HIV/AIDS-related mortality and morbidity, we should recognize and never forget the heroic accomplishments of early AIDS activists such as Michael Lynch and the role they played in the success of AIDS education and treatment over the last twenty years. Silversides has written a passionate and personal book, highlighting a key period in medical and social history, from a Canadian perspective. It is important and captivating reading for health care professionals working in the field of HIV/AIDS and others wanting to learn more about this tumultuous period in medical history.

\section{Gordon Arbess}

Staff Physician

St. Michael's Hospital

University of Toronto

Toronto, Ont. 